\title{
Er friheden taget ud af friskolen?
}

Tore Vincents Olsen

Lektor, Institut for Statskundskab, Aarhus Universitet

\begin{abstract}
Lige præcis friskolerne er en særlig dansk værdi, for de findes ikke magen til andre steder. Det, at man ikke bare ligestiller mindretallet, men giver dem en ekstra støtte, er meget unikt for Danmark. Friskoleloven betyder, at man har ret til at sende sine børn i en skole, som passer med ens forestillinger om, hvad der er en god skole
\end{abstract}

(Bertel Haarder, citeret i Information, 6. juli 2009)

De seneste 15 år har indebåret en række ændringer i lovbestemmelserne om friskolernes ideologiske og pædagogiske frihed. Hvad er baggrunden for ændringerne, har de medført en indskrænkning i skolernes frihed, og er der nok frihed tilbage?

Uddannelse står højt på den danske politiske dagsorden. Det skyldes for det første, at uddannelse anses for at være afgørende for landets konkurrenceevne i den globale økonomi, og for det andet at uddannelse ses som afgørende for at integrere mindretal, især dem med indvandrerbaggrund, i samfundet. De to faktorer er tæt relateret på et strukturelt plan, idet konkurrencepresset på den nationale økonomi gør det stadig sværere at acceptere grupper, som ikke er fuldt integrerede, og som ikke kan bidrage positivt til landets økonomi, især ved arbejdsmarkedsdeltagelse. En tredje faktor er frygten for, at manglende integration kan føre til radikalisering og i sidste instans terroraktivitet hos mindretal, især religiøse. Midlet er at bruge uddannelsessystemet til at socialisere kommende generationer til at blive gode medborgere, der respekterer og gerne praktiserer demokratiet, individuelle rettigheder og ligestilling.

For et grundlæggende liberalt-demokratisk land som Danmark opstår der i forbindelse med uddannelse nogle problemstillinger, da bestræbelsen på at indfri nogle kollektive mål såsom konkurrenceevne og integration kan komme i konflikt med nogle af dets egne grundlæggende principper, nemlig både demokrati og individuelle rettigheder. På det helt grundlæggende plan forbyder liberale principper, at staten forsøger at sindelagskontrollere dens borgere. Statens regulering af borgerne bør kun angå deres ydre adfærd. Ligeledes kan det hævdes, at netop muligheden for at være uenig med flertallet, og herunder også med demokratiet som styreform, må anses for en grundlæggende demokratisk ret. Med andre ord er der grænser for, hvor langt staten kan gå $\mathrm{i}$ at præge kommende borgere gennem $f_{x}$ uddannelsessystemet. Inden for den liberale uddannelsesfilosofi reflekteres dette i diskussioner om, hvad der bør indlæres af værdier i skolen ( $\mathrm{fx}$ tolerance, individuel autonomi, medborgerskab, nationalt tilhørsforhold), hvem der bør have kontrol over skolesektoren (private eller offentlige skoler, forældre eller staten), og hvilken ret henholdsvis forældre, stat og samfund har til at bestemme over børnenes skolegang, herunder hvem der er bedst egnede til at fremme og forsvare børnenes interesser i og rettigheder til uddannelse. Den internationale ret slår fast, at børn har ret til uddannelse, men også samtidig at forældre har lov til at uddanne deres børn i overensstemmelse med deres filosofiske og religiøse overbevisninger ved at sende dem i privatskole eller hjemmeundervise dem. Den giver dermed en forholdsvis stor grad af frihed til forældre til at bestemme over deres børns undervisning. Sidstnævnte betyder dog ikke, at staterne er forpligtet til at understøtte private skoler økonomisk, men at de må tillade, at undervisning i privat regi finder sted (Van Dijk et al 1998, 643-55).

Som Haarders udtalelse ovenfor indikerer, så har Danmark en tradition for ikke blot at tillade oprettelsen af private skoler - eller friskoler - men også for at give dem statstilskud. Den danske friskoletradition er tæt forbundet med det danske frisind og oprinder også til dels af den Grundtvig-Koldske bevægelse, som var frisindets fortaler, og som var meget kritisk over for den statsligt og kirkeligt kontrollerede almue og (senere) folkeskole. Livets skole, som de stod for, gik ud på at skabe folkelig 
oplysning gennem det talte ord, deltagelse og engagement og ikke gennem kateketisk udenadslære (Korsgaard 2005, 214-30, 333-7). Frisindet bestod i at give alle lige ret til at forfølge og forfægte deres synspunkter, herunder gennem uddannelse, samtidig med at man offentligt og med alle verbale midler selv forsvarede, hvad man anså for sandheden, og kritiserede, hvad man anså for usandt og moralsk forkert (Bredsdorff \& Kjældgaard 2008). Fortalere for den danske friskoletradition peger på, at dens grundlovsfæstethed og udmøntning i friskoleloven skal (eller skulle, jf. nedenfor) ses som en demokratisk mindretalsbeskyttelse. ${ }^{1}$

Thorstein Balle, tidligere forstander på Den Frie Lærerskole i Ollerup, ser således friskoletraditionen som et spørgsmål om demokratisk mindretalsbeskyttelse, som vægter forældrenes ret over statens i børnepolitikken i relation til uddannelse og opdragelse. Han peger på, at der er fem frihedsprincipper i den måde, som friskoletraditionen er konstitueret på, nemlig 'den ideologiske frihed, den pædagogiske frihed, den økonomiske frihed, den ansættelsesmæssige frihed og elevfriheden':

Den ideologiske frihed var naturligvis den grundlæggende, altså forældrenes frihed til at vælge, hvilket menneske-, livs- og samfundssyn der skulle styre deres børns opdragelse og undervisning, selv om også disse opfattelser var i stærk modsætning til flertallets. At kunne leve denne ideologiske frihed ud krævede stor frihed på såvel det pædagogiske som det økonomiske og det ansættelsesmæssige område. Ligesom det også var en nødvendighed, at det var skolerne selv - og ikke det offentlige - der kunne afgøre, hvilke børn skolerne skulle optage eller bortvise. Disse fem friheder i forhold til statsmagten blev indtænkt i lovgivningen om de private børneskoler og understøttet økonomisk af staten. Dermed blev de et unikt og fornemt eksempel på det frisind i dansk kultur, som blev udviklet i slutningen af 1800-tallet i de folkelige bevægelser (Balle 2006, 6, kursiv tilføjet).

Det er Balles opfattelse, at friskoletraditionen beskyttede mindretal, hvis ideologiske grundsyn var i stærk modsætning til flertallets, og han etablerer også en klar forbindelse mellem de fem frihedsprincipper og det danske begreb om frisind. Et stridspunkt i den danske friskoledebat er dog, om frisindet strækker sig til accept af skoler, som er baseret på ideologier, der er i modstrid med demokrati- og frihedsprincipper og dermed angiveligt afviser det principielle grundlag for de rettigheder, som de selv baserer sig på.

Denne artikel analyserer, hvad der har motiveret de sidste 15 års ændringer af Lov om friskoler og private grundskoler (herefter 'friskoleloven'), og i hvilket omfang disse ændringer efterlader friheden og frisindet i den danske skolesektor intakt. Dernæst diskuterer den ændringerne i lyset af grundlæggede liberale principper for uddannelse. Spørgsmålet er, om den danske stat er gået for langt i indskrænkningen af skolernes og heraf afledt forældrenes valgfrihed i dens bestræbelse på indfri mål som konkurrenceevne og integration. Diskussionen tager udgangspunkt i en afgrænset række af liberale positioner. I forhold til motiverne for ændringerne i friskoleloven er den teoretiske antagelse, at bekymringer for konkurrenceevne og for integration af mindretal er de bagvedliggende drivere, men at tilslutningen både på højre og venstre side af midten i dansk politik til den danske friskoletradition sætter grænser for, hvor langt staten vil gå i reguleringen af skolernes autonomi. Det næste afsnit ser kort på den historiske udvikling inden for friskolesektoren. Dernæst følger analysen af de fire forskellige lovgivningsmæssige tiltag og deres indhold. Tredje afsnit indeholder en kort vurdering af ændringernes konsekvenser, før det fjerde og sidste afsnit inden konklusionen diskuterer, om friheden er blevet reduceret for meget.

\section{Historisk udvikling}

Der er i dag 14,4 procent af skoleeleverne fra 0. til 10. klasse, der går på en fri grundskole, mens 79,1 procent går i folkeskolen $(2011 \mathrm{tal}) .{ }^{2}$ For de frie grundskoler er tendensen stigende, mens den er faldende for folkeskolen. Der er 537 frie grundskoler og 1318 folkeskoler (2012), og tendenserne er de samme som ved elevtallet. Inden for de senere mange år er antallet af frie grundskoler og antallet af de elever, der går på dem, det højeste. I starten af 1970 var der kun ca. 6 procent af eleverne, der gik i fri- eller privatskole, og de udgjorde dermed en noget mindre gruppe.

Grundlovens $₫ 76$ stipulerer, at:

Alle børn i den undervisningspligtige alder har ret til fri undervisning i folkeskolen. Forældre eller værger, der selv sørger for, at børnene får en undervisning, der kan stå mål med, hvad der almindeligvis kræves i folkeskolen, er ikke pligtige at lade børnene undervise i folkeskolen.

Grundloven indeholder således en undervisningspligt og ikke en skolepligt - som det i sidste instans påhviler forældrene at indfri, hvis de ikke sender deres børn i folkeskolen. Denne undervisning kan indfries via de frie 
grundskoler, såfremt de leverer en undervisning, 'der kan stå mål med hvad der almindeligvis kræves i folkeskolen'. Historisk set har fortolkningen af denne sætning varieret, og det samme har de måder, hvorpå man har kontrolleret, at undervisningen stod mål med folkeskolens (Balle 2001). Det mest uregulerede tidspunkt i reguleringen af friskolerne var i slutningen af 1970'erne, hvor friskolerne ikke behøvede at undervise i alle folkeskolens fag, men kun i de fag, som folkeskolens fagkreds 'naturligt kan opdeles i, herunder også orienteringsfagene, det praktisk-musiske område, og idræt' (Horton-Frida Cirkulæret, 1977, citeret fra Balle 2001, 59). På det tidspunkt udgjorde statstilskuddet samtidig omkring 85 procent af udgifterne til friskolernes drift. Fra 1991 skulle den tilsynsførende, udvalgt af forældrene (forældrenes ansvar for tilsynet har været gældende siden 1933), ikke længere godkendes af ministeriet, men navnet blot meddeles kommunen (Balle 2001, 59-60). Den tilsynsførende skulle dog hvert fjerde år aflægge tilsynsrapport om fagene dansk, regning/matematik og engelsk. Ministeriet kunne i særlige tilfælde træffe beslutning om ekstra tilsyn med en skole. Balle (2001, 60) citerer daværende undervisningsminister Bertel Haarder for i 1991 at mene, at udtrykket skulle dække over, at 'at man kan gøre lige stort set hvad man vil, men når konfirmationsalderen er nået, vil vi godt have garanti for, at folk kan læse og regne og har lidt flere elementære skolekundskaber'. Som Balle (2001) fastslår, er der her tale om en meget, og antagelig fra statens side bevidst, løs forstålse af de krav, som friskolerne skal leve op til.

I dagens optik udviser Haarders udtalelse en overraskende lemfældighed. For så vidt bemærkningen er dækkende for et generelt syn på uddannelse på daværende tidspunkt, hvilket selvfølgelig er tvivlsomt, er der sket meget siden.

I det lange historiske perspektiv har uddannelse været set som afgørende for opbygningen af en kompetent arbejdsstyrke, indfrielse af nationaløkonomiske behov og for skabelsen af en national identitet, herunder som forsvar mod fremmede aggressorer (Kaspersen 2008, 8190). Folkeskoleloven fra 1958 frisatte imidlertid uddannelsen som et autonomt rum for dannelse og demokratisk praksis (Pedersen 2011a, Korsgaard 2010). Dannelsen og demokratiet var formål i sig selv, ikke instrumenter for noget andet.

Dog skaber 1970'ernes og 1980'ernes økonomiske krise et kraftigt fokus på Danmarks internationale konkurrenceevne. Både herhjemme og internationalt begynder en omstrukturering fra velfærdstaten til workfare-staten baseret på en (neo-liberal) forestilling om, at borgerne skal tilskyndes til at tage ansvar for deres eget liv og løbende udvikle deres kompetencer for at være arbejdsmarkedsparate fx gennem 'aktivering' (Torfing 2004).
Velfærdsstaten kan ikke længere tildele rettigheder uden pligter til uproduktive grupper i samfundet. Dens seneste inkarnation, 'konkurrencestaten', koordinerer stadig flere politikområder, herunder uddannelse, med henblik på at styrke nationens internationale økonomiske konkurrenceevne (Pedersen 2011b). OECD's PISA-undersøgelser er et internationalt tegn på dette, og herhjemme afføder skuffende PISA-resultater i 2000 store bekymringer om uddannelsessystemets evne til at uddanne kommende generationer til den internationale konkurrence. Ifølge Pedersen (2011a) og Korsgaard (2010) er ændringen af folkeskoleloven i 2006 det endelige tegn på, at den offentlige uddannelse igen er blevet underlagt et overordnet nationaløkonomisk rationale. Samtidig skifter synet på demokrati i uddannelsen, hvor fokus er gledet fra, at demokratiet skal konstitueres i praksis af elever og lærere på skolen, til at eleverne skal indprentes demokratiske dyder, der svarer til et demokrati, der er givet på forhånd (Pedersen 2011a).

I delvis forlængelse af skiftet til workfare-staten skifter fokus $\mathrm{i}$ indvandrings- og integrationspolitikken fra begyndelsen af 1990'erne også fra rettigheder til pligter, og ikke mindst til værdier (Mouritsen \& Olsen 2013). Indvandrere har pligt til at deltage i samfundet og tilegne sig grundlæggende danske værdier. 'At stille krav' ses både som en social- og integrationspolitisk nødvendighed og som en gerning, der giver indvandrere et mere værdigt liv gennem selvansvarliggørelse (Mouritsen \& Olsen 2013, 695). VK-regeringens øgede vægt på indlæringen af medborgerskabsdyder i folkeskolen havde også en klar reference til indvandrer-unge og deres angiveligt manglende forståelse for demokratiet i Danmark (Jensen 2010). Siden 9/11 2001 har en del af indsatsen over for unge (med indvandrerbaggrund) været baseret på frygten for fundamentalistisk radikalisering og terrorisme. Uddannelsessystemet har skullet opfange og socialisere potentielle terrorister til gode medborgere, om end indsatsen i sin mest eksplicitte form, VK-regeringens antiradikaliseringsplan (Regeringen 2009), først kommer forholdsvis sent i forrige årti (Lindekilde \& Sedgwick 2012).

Spørgsmålet er nu, i hvilken grad friskolesektoren har været udsat for det samme pres, og hvor meget frihed og frisind der er tilbage. Har mindretal i Danmark stadig mulighed for at oprette og drive skoler på et ideologisk grundlag, som er 'i stærk modsætning' til flertallets? $\mathrm{N} x$ ste afsnit kigger på fire centrale ændringer i friskoleloven fra de sidste ca. 15 år, som rettelig kan siges at præcisere, hvor grænserne for skolerne og deres ideologiske ståsted går. 


\section{Reduktionen af friheden i friskolerne?}

Perioden med den store uregulerede frihed til friskolerne lakker mod enden i slutningen af 1990'erne. I forlængelse af Tvind-affæren ændres i foråret 1998 tilsynsbestemmelserne i friskoleloven, og der indføres en bestemmelse om, at undervisningen skal foregå på dansk. Lovgivningen bliver vedtaget uden store protester. Kun Enhedslisten kritiserer, at mindretals mulighed for at blive undervist på deres eget sprog indskrænkes (tyske mindretalsskoler og internationale skoler er dog undtaget fra bestemmelsen). Lovgivningen bunder ikke umiddelbart i hensyn til dansk konkurrenceevne, men sprogbestemmelsen udgør et integrationspolitisk aspekt.

For de næste større ændringer af loven i 2002 og 2005 var det anderledes. I 2002 bestemmes det i forlængelse af den nye VK-regerings integrationspakke, at friskolerne skal forberede eleverne til frihed og folkestyre. I lovforslaget var formuleringen:

Skolerne skal på grundlag af de principper for menneskerettigheder og grundlæggende frihedsrettigheder, der følger af Den Europæiske Menneskerettighedskonvention, forberede eleverne til at leve i et samfund med frihed og folkestyre (L 163 2001/2, 2. samling).

Lovforslaget var direkte motiveret af behovet for integration af tosprogede børn. Det hævdede endvidere, at det hidtil havde været en forudsætning, at friskolerne respekterer grundlæggende individuelle rettigheder, men at der nu er mistanke om, at friskolelovens frihed 'bliver udnyttet til at drive frie grundskoler på et så fundamentalistisk idégrundlag, at det gør eleverne uegnede til at leve i et samfund som det danske med frihed og folkestyre' (L 163 2001/2, 2. samling). Referencen til den europæiske menneskerettighedskonvention (EMRK) synes dermed at sætte de ydre grænser for friheden for skoler, der ønsker statstilskud. Lovforslaget er dog ikke helt klart. På den ene side er det 'ikke hensigten ... at pålægge de frie grundskoler at give udtryk for bestemte holdninger til etiske, religiøse eller politiske spørgsmål m.v.' (L 163 2001/2, 2. samling). Lovforslaget giver mulighed for at skolerne kan have en grundholdning om, at 'manden er kvinden overlegen' eller, at 'et eller flere af principperne for det danske folkestyre er forkerte, eller at der ikke skal være religionsfrihed i Danmark'(L 163 2001/2, 2. samling). På den anden side skal skolerne give eleverne en 'erkendelse af', en 'respekt for' og en 'forståelse af', at der kan være flere forskellige holdninger til politiske, etiske og religiøse spørgsmål samt principperne bag EMRK. Det forbyder en 'undervisning, der bygger på, at konventionen ikke respekteres', fx ved at den indebærer 'religiøs, racistisk eller anden diskrimination eller en anden krænkelse af elevernes eller andres forenings- og ytringsfrihed eller anden rettighed eller frihed, der er beskyttet af EMRK' (L 163 2001/2, 2. samling).

Lovforslaget stiller således ikke umiddelbart krav om, at skolerne skal udstyre eleverne med et bestemt demokratisk etos, men retter sig primært mod at give eleverne en viden om principperne bag demokrati, menneskerettigheder og ikke-diskrimination, og forlanger, at skolerne i handling, hvis ikke i ord, ikke bryder med den eksisterende lovgivning, der baserer sig på disse principper. Lovforslaget indeholder dermed ikke en 'sindelagskontrol' af borgerne, og det er kun kontroversielt fra et valgfrihedssynspunkt, for så vidt at kravet om, at man giver eleverne en bestemt viden, kan besværliggøre overførelsen af skolens og forældrenes værdi- og verdenssyn til eleverne (se Burtt 1994).

Lovforslaget motiveredes af et hensyn til integration, et kollektivt formål, men kan også ses som en sikring af børnenes grundlæggende individuelle interesser og rettigheder gennem tilvejebringelsen af en tilstrækkelig videnbasis for at kunne fungere som (fremtidige) samfundsborgere i Danmark.

I den endelige lov blev referencen til EMRK taget ud, fordi nogle af oppositionspartierne syntes, at den var for krævende og efterlod for lidt plads til alternative anskuelser. SF mente, at det var en frihedsret at være uenig i menneskerettighederne (A. Frandsen, i Folketinget 2002). De Radikale så det som en selvfølgelighed, at skolerne ikke havde frihed til at undervise i modstrid med 'grundloven, demokratiet eller et samfund, der har frihed og folkestyre', men mente også at friskolernes eksistens skulle sikre forældrene og børn alternativer til folkeskolen, da folkeskolens opgave netop er at 'opdrage, uddanne, oplære, danne børnene' på en bestemt måde (M. Jelved i Folketinget 2002).

Den største konflikt angik imidlertid en udvidelse af tilsynet med elevernes resultater og skolernes fag til at gælde ikke bare dansk, matematik/regning og engelsk, men også naturfagene og samfundsvidenskab/historie. Oppositionspartierne mente, det ville indebære, at friskolerne skulle ligne folkeskolen alt for meget og dermed reducere forskelligheden. Det forstærkede tilsyn endte med kun at blive udvidet til at sikre, at undervisningssproget er dansk, og udelod stadig naturfagene og samfundsvidenskab/historie. Alle partier på nær Dansk Folkeparti og Enhedslisten stemte for det endelige forslag. DF mente, at det var for slapt, mens Enhedslisten gav andre grunde.

I VK-regeringens næste større ændring af friskoleloven i 2005 refereres der direkte til PISA-undersøgelserne og en ambition om at sikre 'et højt fagligt niveau i grund- 
skolen' (L 105 2004/5, 2. samling). Regeringen hævder, at friskolerne klarer sig lidt dårligere end folkeskolen, og især at skoler med mange tosprogede klarer sig dårligere. Derfor skal der defineres mere specifikke del- og slutmål for friskolernes undervisning, og tilsynsreglerne skal strammes. Hvis skolerne ikke vælger at følge folkeskolens del- og slutmål som defineret i 'Fælles mål' (Undervisningsministeriet 2013), skal de lave målbeskrivelser og undervisningsplaner for alle fag, så det kan vurderes, om de leverer en undervisning, der står mål med folkeskolens. ${ }^{3}$ Undervisningsplanerne skal også vise, hvordan undervisningen giver 'mulighed for elevens alsidige personlige udvikling'. Det indebærer, 'at skolen skal tilgodese alle sider af elevens udvikling, herunder den åndelige, intellektuelle, musiske, fysiske og sociale' (L 105 2004/5, 2. samling). Lovforslaget har også en meget tæt reference til integrationsdagsordenen og bekymringen for politisk ekstremisme. Friheds- og folkestyrebestemmelsen udvides til dens nuværende ordlyd:

\section{Skolerne skal efter deres formål og i hele deres virke forberede eleverne til at leve i et samfund med frihed og folkestyre samt udvikle og styrke elevernes kendskab til og respekt for menneskerettigheder og grund- læggende frihedsrettigheder, herunder ligestilling mellem kønnene (Friskoleloven $\$ 1$, stk. 2).}

Dermed gælder bestemmelsen ikke bare undervisningen, men alle aktiviteter på skolen. Den indsættes for at sikre 'at fundamentalistiske eller ekstremistiske handlinger, der begrundes i religiøse hensyn m.v., men som alvorligt strider mod' menneskerettigheder, grundlæggende frihedsrettigheder og kønsligestilling 'ikke kan finde sted på eller fra en fri grundskole' (L 105 2004/5, 2. samling).

Som i 2002 er lovforslaget tvetydigt i forhold til grænserne for skolernes ideologiske frihed, da den også indfører en bestemmelse om, at friskolerne inden for rammerne af denne lov og lovgivningen i øvrigt [kan] give undervisning, der stemmer med skolernes egen overbevisning og tilrettelægge undervisningen i overensstemmelse med denne overbevisning' (L 105 2004/5, 2. samling). Dette tjener til at give skolernes grundlæggende frihed behørig vægt i vurderingen af, om de lever op til lovgivningen. Samtidig indeholder loven en bevidst indskrænkning af friheden, da det nu er uforeneligt med frihed- og folkestyrebestemmelsen, hvis en skole bygger på en overbevisning om at 'manden er kvinden overlegen', eller 'et eller flere af principperne for det danske folkestyre er forkerte, eller at der ikke skal være religionsfrihed i Danmark eller andre lande'. Ligeledes skal skolerne uanset deres overbevisning undervise i 'udviklingslæren', 'den humane biologi' og give seksualundervisning. Insisterer skolerne på et ideologisk grundlag, hvor sådanne overbevisninger indgår, kan de ikke længere modtage offentligt tilskud. Dermed er friheden til at undervise i overbevisninger, som står i 'stærk modsætning til' flertallets, reduceret betydeligt, om end ikke fuldstændig udelukket, da det stadig er muligt i 100 procent privatfinansierede skoler. ${ }^{4}$

Det er ikke fra loven alene tydeligt, om skolerne skal udstyre eleverne med et demokratisk etos eller blot med en viden om grundlæggende principper og deres retslige implikationer. Formuleringerne om, at skolerne i hele deres virke skal forberede eleverne til et samfund med frihed og folkestyre, peger dog i denne retning. Ligeledes forudsætter vejledningen i, hvordan man fastslår, at en skole lever op til friheds- og folkestyrebestemmelsen, at der ikke bare er tale om viden men også en praksis i undervisningen, som bør være demokratisk og dialogisk og formidle en viden 'som satter sig spor $i$ elevernes handlinger og fardigheder' (BEK nr. 1172 af 12/12/2011, bilag 3, kursiv tilføjet).

Lovændringen, der vedtages med henvisninger til den internationale konkurrenceevne, integrationsdagsordenen og faren for ekstremisme, indskrænker således friheden for friskolerne og synes at fordre både indlæring af viden om grundlæggende liberal-demokratiske principper og et bestemt demokratisk etos. Dermed har loven en ambition om at påvirke elevernes sindelag i en bestemt retning.

Loven blev vedtaget uden støtte fra De Radikale, Socialistisk Folkeparti og Enhedslisten, der så den som en underminering af det frie uddannelsesvalg og som udtryk for mistillid til forældrenes og skolernes evne til at forvalte deres frihed ansvarligt og dermed som centralisme og paternalisme (Uddannelsesudvalget 2005). Baggrunden for modstanden var i særdeleshed fastsættelsen af del- og slutmål for undervisningen i en række fag, som oppositionspartierne på linje med deres modstand mod det oprindelige forslag fra 2002 mente svarede til en ensretning af undervisningen i friskolerne.

En vigtig debat har handlet om tilsynet med friskolerne og dermed om, hvem der har kontrollen med, hvordan lovgivningens krav skal fortolkes i praksis. Siden 1933 har det principielt set været forældrenes ansvar at føre tilsyn med de enkelte skoler, mens Undervisningsministeriet har holdt øje med skolernes resultater og har kunnet gribe ind i specifikke sager, hvor der har været indikation på mangelfuld skoledrift. Efter ændringen i 2005 skulle forældrene udpege en uafhængig tilsynsførende eller overlade det til kommunalbestyrelsen at udøve tilsyn. Ministeriet holdt særligt øje med de skoler, som ikke anvendte folkeskolens afgangsprøver, overvågede fri- 
skolernes resultater generelt og inspicerede specifikke skoler, hvor der var indikationer på mangler ved skoledriften. I 2006 blev der på friskolernes anmodning nedsat en arbejdsgruppe bestående af skolesammenslutningerne og ministeriet, der skulle komme med forslag til forenkling af tilsynet. I 2010 blev loven så ændret, så skolerne nu skal udpege en certificeret tilsynsførende, bede kommunalbestyrelsen om at udpege en eller, alternativt, udføre 'selvevaluering' efter en model som er godkendt af ministeriet. Certificeringen af tilsynsførende sker på baggrund af kurser udviklet af skolesammenslutningerne, ligesom de har udviklet de selvevalueringsmodeller, der godkendes af ministeriet. Derudover indebar lovændringen, at ministeriet skal vægte testresultater mere i tilsynet af akademiske resultater for derved at give plads til mere fleksibilitet $\mathrm{i}$ undervisningsmetoderne.

I dag er ministeriets tilsyn baseret på skolernes resultater, herunder karakterer og overgang til ungdomsuddannelser, på selvevalueringer og på de tilsynsførendes rapporter samt på input fra forældre eller medierne. Udvælgelsen til tilsyn er generelt baseret på resultater, mens selve tilsynene ser på undervisningsmaterialerne og undervisningspraksis. Derudover udarbejder ministeriet årlige tilsynsplaner med særligt fokus. I 2009 i forbindelse med VK-regeringens antiradikaliseringsplan fik 25 udvalgte skoler fx undersøgt deres undervisning i 'frihed og folkestyre' med henblik på eventuelle nye lovændringer. Ministeriet kan også sætte en skole under særligt tilsyn, hvis det har grund til at tro, at den ikke lever op til lovens krav, eller hvis den ikke har efterlevet et påbud fra dens tilsynsførende om at rette op på forholdene.

Hvad angår tilsynet med friheds- og folkestyreklausulen i friskoleloven, har ministeriet udviklet en fleksibel model, som beror på en helhedsvurdering af skolerne på baggrund af deres grundholdning, mål og intentioner med undervisningen, deres konkrete undervisning, resultater samt skolernes samlede virksomhed og kultur (Undervisningsministeriet 2009). Idéen er, at der er mange forskellige måder, hvorpå skolerne kan leve op til kravet om frihed og folkestyre i deres praksis. Ministeriets generelle erfaring er, at hvor der er problemer, skyldes det vidensniveauet og ikke indprentningen af kontroversielle holdninger hos elever. Kontroversielle holdninger vil dog også kunne føre til en negativ vurdering af skolerne på dette område (Interview med Anders Andersen 2011).

\section{Effekterne af lovgivningen}

Det er ikke muligt her at lave en fuldstændig undersøgelse af lovgivningens effekter. Før ændringen i 2002 blev tre muslimske skoler lukket, enten fordi de ikke kunne leve op til de faglige standarder, eller fordi de ikke var uafhængige enheder. Efter 2002 er en muslimsk skole og en Pinsebevægelse-skole blevet lukket med henvisning til friheds- og folkestyrebestemmelsen, mens to muslimske skoler og en Scientology-skole blev lukket pga. svigtende fagligt niveau.

Interview med folk i friskolesektoren afslører en opfattelse af, at især muslimske skoler føler sig sat under mistanke og ikke mindst diskriminerede i forbindelse med udvælgelse til ministerielt tilsyn. Det gjaldt især VKregeringens antiradikaliseringsplan fra 2009. En effekt af ændringerne er angiveligt, at mange skoler ikke mener, at de har ressourcer til at undervise på en måde, der adskiller sig væsentligt fra folkeskolens. Det kræver nemlig et stort dokumentationsarbejde fra skolens side og indebærer en højere risiko for at blive underkastet tilsyn. Effekten er antageligt, at det reducerer udnyttelsen af de frihedsgrader, der formelt eksisterer i lovgivningen (Interview med A. Pedersen 2011, E. Lilliendal 2011).

To skoleledere på muslimske skoler, som har været underkastet tilsyn fra ministeriet, udtrykker $\mathrm{i}$ interview stor usikkerhed i forhold til, hvordan man kan dokumentere, at skolen fremstår som demokratisk, og de føler, at det er vilkårligt, om en skole bliver vurderet til at indfri lovens krav eller ej. Samtidig rapporterer de en generel følelse af mistænkeliggørelse og eksklusion ikke mindst blandt eleverne, hvor det at være muslim gør det 'umuligt' at blive en del af samfundet, uanset hvor meget man anstrenger sig, fordi muslimer fra politisk hold bevidst bliver kædet sammen med trusler mod demokratiet og terror (Kjærgaard \& Larsen 2010, 68-75).

\section{Er der nok frihed tilbage?}

Analysen viser, at friheden i friskolen er blevet reduceret. Især lovændringen i 2005 reducerer muligheden for at drive skoler på et ideologisk grundlag, som er i 'stærk modsætning' til flertallets. Skoler, der bevarer et sådant grundlag, kan ikke få statsstøtte og må basere sig på 100 procent privatfinansiering. Ligeledes er det omkostningsfulde dokumentationsarbejde, der pålægges skoler, hvis undervisning afviger meget fra folkeskolens, reelt med til at reducere friheden trods lovgivningens formelle frihedsgrader. Endelig er det højst sandsynligt, at usikkerheden omkring, hvad der skal til for at leve op til lovens krav, i sig selv er med til at reducere udnyttelsen af lovens frihedsgrader. Rettighedsusikkerhed virker ofte begrænsende for frihedsudøvelse.

Som analysen viser, kan en del af frihedsreduktionen spores tilbage til en ambition om at sikre integration og modvirke ekstremisme, segregering og potentielt terror. I andet led ligger bestræbelser på at sikre konkurrenceevnen ved at $ø$ ge kvaliteten i grunduddannelserne. Da friskolerne udgør en stigende del af grundskoleundervisningen, falder de naturligt under statens bestræbelser på 
at sikre kvaliteten i grundskolen. Integration og konkurrenceevneforbedring er forbundne størrelser, da velintegrerede borgere bidrager mere til samfundsøkonomien.

Tendensen har været en præcisering af kravene til friskolerne og dermed en mere centraliseret kontrol. Der er dog stadig decentrale elementer i friskolelovgivningen. Deres ideologiske frihed understreges således ved ændringen i 2005. Forældrenes fortsatte ansvar for tilsynet med skolerne og skolernes mulighed for selvevaluering er et andet decentralt element. Både tilsynsformen og selvevalueringsmodellerne giver skolerne mulighed for gennem deres foreninger at påvirke den måde, hvorpå de skærpede krav i lovgivningen fortolkes, selvom kravene blev opstillet mod skolernes ønsker. Endelig er den danske friskolelovgivning stadig forholdsvis fleksibel i europæisk sammenligning.

Ændringerne strider ikke mod grundlovens $₫ 76$ (Ross 1966, 767-8, jf. dog 769). Spørgsmålet er dog stadig, om reduktionen af friheden kan forsvares fra et principielt synspunkt. Som nævnt i indledningen er det kontroversielt, hvis en liberal stat går ind og kontrollerer sindelaget hos borgerne, og dét sætter visse grænser på, hvad staten kan gøre i forhold til undervisningen af kommende borgere. Den liberal-demokratiske stat er grundlæggende baseret på frivillig tilslutning hos borgerne som dens underliggende legitimitetsprincip og kan derfor ikke indoktrinere dem til en accept af dens magtudøvelse eller til bestemte ideologiske positioner ( $\mathrm{fx}$ Brighouse 1998, Gaus 2005). Modsat kan der argumenteres for, at opretholdelsen af en liberal-demokratisk statsordning som en nødvendig betingelse for sikringen af borgernes lige frihed forudsætter visse færdigheder og grundindstillinger hos borgerne, herunder evne for en politisk autonomi, der indebærer, at man er i stand til at vurdere, hvad der retmæssigt falder under den offentlige magts jurisdiktion (Gaus 2005, Gutmann 1995). Mellem liberale er der her uenighed om, hvorvidt staten $\mathrm{fx}$ via uddannelse kan påvirke borgerne til at udvikle disse færdigheder og grundindstillinger og i så fald på hvilke måder. En central diskussion er, om demokratiske værdiorienteringer må indprentes i elever på en autoritær måde eller højst kan befordres indirekte gennem en demokratisk undervisnings- og skolepraksis (fx Gutman 1995 vs Brighouse 1998).

Der er et bredt spektrum af positioner inden for den liberale diskussion om, hvad der bør undervises i, og hvem der bør stå for undervisningen. I den ene ende af spektret argumenterer Kukathas (1992) således for en minimal indblanding fra statens side i forskellige fællesskabers selvorganiserede undervisning. Det skyldes, at værdier som 'autonomi', hvad enten politiske eller personlige, er kontroversielle opfattelser af det gode liv, som en liberal stat ikke legitimt kan prioritere over andre værdier, fx stærkt religiøse livsværdier. Den grundlæggende frihed i den liberale stat er foreningsfriheden ('freedom of association'). Statsindgreb skal kun sikre, at mindretalsmedlemmer har mulighed for frit at tilslutte sig og forlade de mindretal, de er en del af. Det sker ved, at det omgivende liberale samfund 'tilbyder' alternative livsmuligheder og garanterer foreningsfriheden, typisk i sammenhæng med andre liberale friheder. Så længe individer underlægger sig forskellige mindretals evt. ikke-liberale værdier og praksisser, kan staten ikke gribe ind, heller ikke i forhold til fx børn, hvis forældre ikke prioriterer uddannelse overhovedet, da staten ikke legitimt kan prioritere et liv baseret på oplyste og rationelle valg over andre former for liv (Kukathas 1992, 126). Undervisning kan være privatorganiseret med meget få begrænsninger og krav fra statens side. Kukathas adresserer dermed ikke direkte spørgsmålet om forudsætninger for politisk autonomi som grundlag for den liberale stat men antager, at disse opstår og eksisterer i tilstrækkelig grad i liberale samfund, uden at staten gør noget særligt for at fremme dem.

Herimod argumenterer Galston (1995) for, at staten må kunne kræve, at den uddannelse, børn får, gør dem i stand til at fungere som borgere i det liberale samfund, så samfundet kan opretholde de principper, som sikrer, at diversiteten i 'opfattelser af det gode liv' beskyttes. Det centrale princip er tolerance forstået som den principielle afvisning af at bruge statsmagt til at påtvinge andre ens opfattelse af det gode, og at man ikke tvangsmæssigt kan rekruttere og fastholde medlemmer af kulturelle og religiøse mindretal (Galston 1995, 528). Netop denne tolerance giver store muligheder for at gøre undtagelser for $\mathrm{fx}$ religiøse mindretal i forhold til uddannelse, især i forhold til mindretal ( $\mathrm{fx}_{\mathrm{x}}$ the Amish i USA) som afskriver sig visse rettigheder, som samfundet ellers stiller til rådighed (Galston 1995, 529). Samtidig er der dog en del krav til den uddannelse, som børn skal have, for at de som fremtidige selvstændige voksne har en reel mulighed for at forlade de mindretal, de indgår i. Staten bør således kunne stille krav om, at børn udstyres med de overbevisninger, kompetencer og dyder, der er forudsætningen for 'liberalt medborgerskab', og at de som enkeltpersoner har tilstrækkelig viden og evne til at vurdere alternativer og deltage i andre livsformer, samt frihed fra hjernevask og andre former for ikke-fysisk tvang.

Gutman (1995) peger på, at det er nødvendigt for den liberal-demokratiske stat at sikre, at borgerne er i stand til at udøve deres politiske autonomi på en kompetent måde, hvilket indebærer en reflekteret forholden sig til, hvad der tjener almenvellet og dermed også, hvor grænsen mellem det offentlige og private bør gå. Hun hævder i modsætning til Galston, at 'tolerance' ikke er nok i 
forhold til at sikre grundlæggende lighed i samfundet, idet omgangen mellem forskellige grupper i det politiske liv og på arbejdsmarkedet kræver gensidig respekt og tilslutning til et ikke-diskriminationsprincip (Gutman 1995, 561). Af denne grund er Gutman særdeles skeptisk over for at give undtagelser og særrettigheder til (religiøse) mindretal, herunder også at lade private skoler selv bestemme deres undervisnings indhold. Gutman understreger, at hendes position baserer sig på en politisk liberalisme og ikke en moralsk eller perfektionistisk liberalisme, der vægter personlig autonomi som livsideal. Personlig autonomi indebærer, at individet lever på en måde, hvor det træffer aktive reflekterede valg mellem forskellige (autonomibevarende) valgmuligheder i stedet for konventions- eller autoritetstro at følge udefra givne normer og verdensanskuelser. Samtidig tilstår Gutman, at det i praksis er svært at skelne mellem den form for uddannelse, der fremmer politisk autonomi, og den, der fremmer en personlig, og at det derfor er usandsynligt, at førstnævnte ikke vil bidrage til udviklingen af personlig autonomi (Gutman 1995, 564-5).

Igen andre liberale argumenterer for, at uddannelsen skal være med til at danne det personligt autonome individ ud fra opfattelser af, at barnet har en individuel interesse i og ret til selv at kunne bestemme sit liv og have en 'åben fremtid' (Feinberg 1980), og/eller at evner svarende til dem, der er nødvendige for personlig autonomi, også er nødvendige for, at barnet nu eller senere kan benytte sig af de rettigheder, som det liberale samfund stiller til rådighed; og for at barnet som voksen har de kritiske evner til rådighed, som muliggør en selvstændig vurdering af den liberale stats krav på legitimitet (Brighouse 1998). Især Brighouse kritiserer Galston og Gutman for at ville indprente demokratiske værdier på en dogmatisk måde, der strider mod princippet om frivillighed i accepten af den liberale stats legitimitet. I stedet har børn ret til en undervisning, som ikke stipulerer personlig eller politisk autonomi som mål i sig selv, men som faciliterer den, og som kan suppleres af viden om sociale og politiske institutioner, forskellige politiske ideologier og måder at håndtere politiske konflikter på, så de får mulighed for at agere som kompetente borgere (Brighouse 1998, 735-6).

Sammenlignes der med formuleringerne om frihed og folkestyre i friskoleloven, kan disse placeres inden for rammerne af en generel 'politisk liberalisme' med vægt på at sikre evnerne til at udøve politisk autonomi og en respekt for andres rettigheder og ligestilling i samfundet. Anvisningerne i loven og i bekendtgørelsen om, hvordan man konstaterer, at skolerne opfylder friheds- og folkestyrebestemmelsen, synes at foreskrive indlæringen af et bestemt demokratisk etos på måder, som både libertære som Kukathas og autonomi-faciliterende liberale som
Brighouse ville være skeptiske over for. Bestemmelserne om elevens 'alsidige udvikling', som skal sikres gennem indfrielsen af undervisningens del- og slutmål, bærer visse ligheder med udviklingen af en mere personlig autonomi, et livsideal som er mere kontroversielt. Friskoleloven er dog her meget mere tilbageholdende end fx folkeskoleloven, som eksplicit siger, at folkeskolen skal sigte mod, at 'eleverne udvikler erkendelse og fantasi og får tillid til egne muligheder og baggrund for at tage stilling og handle' (folkeskolelovens $\$ 1$, stk. 2) - og som dermed ligger meget tættere op ad udvikling af personlig autonomi.

Spørgsmålet er, om det er for meget at kræve, at friskolerne skal udvikle politisk autonomi hos eleverne. Svaret afhænger af, hvordan dette forstås og praktiseres. Hvis der er tale om udvikling af forudsetninger for politisk autonomi og ikke indoktrinering til accept af staten og dens institutioner, er det umiddelbart et rimeligt krav. Den liberale stat forudsætter evner for politisk autonomi hos borgerne, da den baserer sig på et grundlæggende legitimeringsprincip om, at dens magtudøvelse skal kunne retfærdiggøres over for alle, der er underlagt den (Gaus 2005). For at kunne indgå i en proces, hvor borgerne over for hinanden retfærdiggør den offentlige magts anvendelse, at de er i stand til at skelne mellem, hvad der er gode grunde for dem selv, og hvad der er gode grunde for andre, og dermed også mellem det offentlige og det private. Det indebærer blandt andet, at de er i stand til at se verden fra andre synspunkter end deres eget. Og det udelukker, at de kun baserer deres politiske aktivitet på fx en dogmatisk, religiøs overbevisning, hvor evnen til at anerkende eller tolerere andres politiske ståsted alene afgøres af, hvad deres egen religiøse overbevisning tilsiger. På kort form: Den liberal-demokratiske stat forudsætter, at borgerne har evne for politisk autonomi, og det er derfor ikke i umiddelbar konflikt med dens grundprincip at forvente, at borgerne besidder disse evner, herunder at de opnår dem gennem statssponsoreret uddannelse.

Hvis man på den anden side forstår kravet om politisk autonomi som indlæringen af et bestemt demokratisk etos, hvilket de senere stramninger af friskoleloven og dens fortolkning synes at indikere, forekommer kravet til frihed og folkestyre mere problematisk, fordi det går imod princippet om en frivillig tilslutning til og accept af den liberale stats autoritet. Hertil kommer bekymringer om, hvorvidt staten og dens repræsentanter er bedre end borgerne selv til at afgøre, om borgerne er demokratisk sindede, om faren ved at give staten ret til at afgøre dette samt tvivl om effekten af at bruge statslig tvang til at skabe et bestemt etos og sæt af overbevisninger. Tvang får ikke nødvendigvis folk til at ændre overbevisning.

Paradoksalt set kræver indlæringen af forudsætningerne for autonomi en mere dialogisk og demokratisk 
praksis i undervisningen, end en ren indprentning af værdier nødvendigvis indebærer (Brighouse 1998). Paradoksalt fordi understregningen af indlæringen af et demokratisk etos også synes at lægge vægt på en demokratisk praksis i skolen som en måde at sikre sig, at demokratiske værdier ikke blot er noget, eleverne har på et abstrakt vidensniveau, men også er noget, de udviser gennem deres deltagelse i undervisningen. Netop det sidste aspekt ville dog ikke indgå i vurderingen fra en autonomi-faciliterende tilgang til autonomi. Og her synes den danske fortolkning af kravene om frihed og folkestyre umiddelbart at gå for langt.

Et andet led $\mathrm{i}$ vurderingen af rimeligheden af kravet om frihed og folkestyre mv. kunne være, hvordan et liberaldemokratisk flertal skal forholde sig strategisk til interne mindretal, som ikke tilslutter sig liberal-demokratiske principper. Det vil ofte være kontekstafhængigt, hvilke tilgange der virker bedst. Danmark har en tradition for at være forholdsvis tilbageholdende med at forbyde organisationer, medmindre det fremgår tydeligt, at de vil fremme deres målsætninger med vold. Spørgsmålet er, om denne laissez faire-tilgang giver mulighed for at 'tage trykket af' ekstremistiske miljøer, som ville have vokset under en meget mere restriktiv linje. Bader (2007, kap. 2) hævder således med nogen sandsynlighed, at det er den institutionelle interaktion med andre grupperinger gennem demokratiske institutioner, som i første omgang leder til tolerance på et praktisk niveau hos fundamentalistiske religiøse grupper, og som ender med, at de tilslutter sig princippet om demokratiets forrang for religionen $\mathrm{i}$ forhold til politiske beslutninger. Typisk er det tolerancen og den demokratiske attitude, der udvikler sig først, mens der senere opstår ændringer i (fortolkningen af) de religiøse doktriner, således at den 'praktiske accept' også ender med at blive en principiel accept (Bader 2007, kap. 2). Pointen er, at ved at tillade mindretal at forme deres egne organisationer, herunder skoler, får man bedre muligheder for at etablere en institutionaliseret interaktion med dem.

Netop konteksten kan være afgørende for, hvordan et givet policy-initiativ virker. Studier antyder således, at visse elementer i VK-regeringens antiradikaliseringsprogram fra 2009 havde den modsatte effekt af den tiltænkte (Lindekilde \& Sedgwick 2012, 59-61). Som nævnt ovenfor er der indikationer på, at den del af indsatsen, der rettede sig mod muslimske friskoler, var med til at fremmedgøre muslimske elever fra det danske samfund snarere end at bidrage til deres inklusion. Dette beroede antageligt på en kompleks interaktion mellem den politiske diskurs i offentligheden og de konkrete lovgivningsmæssige og administrative tiltag (tilsyn) rettet mod skolerne (Kjærgaard \& Larsen 2010, 68-75).
I denne sammenhæng, såvel som generelt, virker det uheldigt, at der mangler en præcision af, hvad der skal til for at leve op til kravet om at forberede eleverne til 'frihed og folkestyre'. Intentionen bag ministeriets brug af helhedsvurderinger i stedet for rigid indfrielse af bestemte kriterier kan måske være god nok. Men interviews indikerer som nævnt, at denne tilgang producerer en stor grad af (rets)usikkerhed i forhold til, hvad der skal til for at leve op til lovens krav. Det forstærkes af, at der ikke umiddelbart skelnes klart mellem et nødvendigt vidensniveau på den ene side og indlæringen af et demokratisk etos på den anden side. En mere klar model ville basere sig på vidensdimensionen, da den alt andet lige er nemmere at måle.

Fra et principielt såvel som fra et strategisk synspunkt er der således elementer i friskolelovgivningens frihedsog folkestyrebestemmelse og dens administration, som er problematiske på den indholdsmæssige side og i forhold til effekterne.

Men billedet er ikke entydigt. For det decentrale element $i$ vurderingen af skolernes indfrielse af lovens mål gennem forældreforankret tilsyn og selvevalueringer gør, at forældre og skolerne, via deres foreninger i praksis, er med til at fortolke standarderne for vurderingerne. Selvom Undervisningsministeriet i sidste instans afgør, om en skole kan opnå tilskud, er ministeriet ikke alene i vurderingerne af, om forudsætningerne for autonomi er til stede. Herudover giver den danske lovgivning med dens undervisningspligt og ikke skolepligt fortsat mulighed for, at forældre kan privatfinansiere deres børns uddannelse 100 procent, hvis de ikke ønsker at være underlagt friskolelovens bestemmelser (jf. dog note 4). Bestemmelserne bliver således sanktioneret med fratagelse af tilskud og ikke tvang i snæver forstand.

Tiltagene gennem 00 'erne har også været orienteret mod at sikre kvalitet i uddannelsen. Det er rimeligt set fra de fleste liberale positioner (dog jf. Kukathas 1992). Viden er en forudsætning for blandt andet politisk og personlig autonomi. At sikre den faglige kvalitet i skolen kan ses som både en måde at fremme et kollektiv formål på, $\mathrm{fx}$ den nationale konkurrenceevne og integration, men kan også ses som en sikring af børnenes rettigheder til uddannelse. Ud fra en liberal betragtning er det betænkeligt, hvis uddannelsen bliver instrumentaliseret til fordel for kollektive mål, som reducerer den videns- og færdighedstillæring, der sker til individets egen interesse (hvordan den end defineres). Som nævnt har der angiveligt været et skifte i måden at anskue folkeskolen på, således at det er mere klart, at uddannelsen skal tjene brede samfundsøkonomiske mål og ikke blot være et frirum for personlig dannelse og demokrati. Det er ikke klart, at friskolen har 
været udsat for helt samme grad af instrumentalisering, selvom tendensen peger i den retning.

Kvalitetssikringen har dog medført et højere krav om dokumentation, som i praksis synes at reducere diversiteten hos friskolerne. Især for mindre skoler er udarbejdelsen af uddannelsesplaner, del- og slutmål mv. en tung øvelse, der kan afskrække dem fra at eksperimentere med alternative ideologiske og pædagogiske grundlag. I den forbindelse kan man argumentere for, at det ikke er strengt nødvendigt at regulere skolernes in- og throughput så meget, som den danske lovgivning lægger op til med bestemmelserne om uddannelsesplaner, del- og slutmål for hovedparten af fagene. En mindre indgribende metode er at følge skolernes resultater i form af eksamenskarakterer og overgang til ungdomsuddannelser. ${ }^{5}$

\section{Konklusion}

Analysen har vist, at ændringerne af friskolelovgivningen inden for de sidste 15 år har præciseret og reduceret friheden for friskolerne i Danmark. Bag denne udvikling har ligget hensyn til Danmarks konkurrenceevne og ikke mindst til bestræbelser på at integrere mindretal og undgå politisk og religiøs ekstremisme. De to (tre) hensyn er tæt forbundne. På spørgsmålet om hvorvidt de præciserede og øgede krav til friskolerne om at forberede eleverne til frihed og folkestyre samt specificere mål for deres uddannelse i sammenligning med folkeskolen har taget for meget frihed ud af friskolerne, må svaret både være nej og ja. Nej, fordi det er i overensstemmelse med det grundlæggende legitimeringsprincip for den liberaldemokratiske stat at forvente, at borgerne besidder forudsætningerne for udøvelsen af politisk autonomi, og fordi den danske lovgivning i stort omfang udøver en decentral kontrol med, om skolerne lever op til kravene, som inddrager skolerne og forældrene selv på forskellig sæt og vis. Ja, fordi der synes at være et problematisk krav om, at skolerne indprenter et demokratisk etos i eleverne, hvilket skurrer mod det liberal-demokratiske legitimeringsprincip, og fordi der i vurderingen ligger en usikkerhed om, hvad der skal til for at indfri lovens krav, og endelig fordi det er omkostningsfuldt for især mindre skoler at skulle dokumentere, at deres undervisning står mål med folkeskolens. Her ville en tilgang baseret på viden frem for etos og på baggrund af målbare (eksamens-) resultater (outcome) give en højere grad af både sikkerhed og fleksibilitet. Det er ikke alt, hvad den liberale stat forudsætter, som nødvendigvis kan sanktioneres eller fremmes direkte via lovgivning.

\section{Litteratur}

Balle, T 2001, “"Stå mål med“ - Om det offentliges krav til indholdet af den private børneundervisning 1814-2001' Uddannelseshistorie vol. 35, pp. 38-69.

Balle, T 2006, En historisk belysning. Undervisningsministeriets Tidsskrift for Uddannelse, vol. 9, pp. 3-8.

Bader, V 2007, Secularism or Democracy?, Amsterdam University Press, Amsterdam.

Bredsdorff, T \& Kjældgaard, L.H. 2010 Tolerance - Eller hvordan man larer at leve med dem man hader, Gyldendal A/S.

Brighouse, H 1998, 'Civic Education and Liberal Legitimacy, Ethics, vol. 108, pp 719-45.

Burtt, S 1994, 'Religious parents, secular schools: A liberal defense of an illiberal education', Review of Politics, vol. 56, no. 1, pp. 51-70.

Feinberg, J 1980, 'The Child's Right to an Open Future' in idem 'Freedom and Fullfilment: Philosophical Essays', Princeton University Press, Princeton, NJ, pp. 124-53.

Folketinget 2002, Første Behandling af L 163, 4. april 2002, Folketinget. URL:http://webarkiv.ft.dk/?/samling/20012/menu/00000002. htm

Galston, W A 1995, 'Two Concepts of Liberalism', Ethics, vol. 105, pp. 516-534.

Gaus, G F 2005, 'The Place of Autonomy within Liberalism' in J Christman \& J Rogers (red.), Autonomy and the Challenges to Liberalism, CUP, Cambridge, pp. 272-306.

Gutmann, A 1995, 'Civic Education and Social Diversity, Ethics, vol. 105, pp. 557-579.

Jensen, K 2010, Citizenship Education in Denmark, CIVITURN Workpackage on Education, Department of Political Science, Aarhus.

Kaspersen, LB 2008, Danmark $i$ Verden, Hans Reitzels Forlag, København.

Kjærgaard, K \& Larsen, MØ 2010, På vej mod en fælles og tryg fremtid? Et governmentality-perspektiv på anti-radikalisering, Speciale, Institut for Statskundskab, Aarhus Universitet, Aarhus.

Korsgaard, O. 2012, Kampen om folket: Et dannelsesperspektiv på dansk historie gennem 500 år, Gyldendal, København.

Korsgaard, O 2010, 'Samfundets Trosbekendelse', Politik, vol. 13, no. 1 , pp. 44-52.

Kukathas, C 1992, 'Are there any Cultural Rights, Political Theory, vol. 20 , no. 1 , pp. $105-39$.

Larsen, C (red.) 2010 Realskolen gennem 200 år, bd. 1 +2, København: Danmarks Privatskoleforening.

Lindekilde, L \& Sedgwick, M 2012, 'Impact of Counter-Terrorism on Communities: Denmark Background Report', Institute for Strategic Dialogue, URL: http://www.strategicdialogue.org/Country_report_Denmark_AD_FW.pdf

Mouritsen, P \& Olsen, T V 2013, 'Denmark Between Liberalism and Nationalism', Ethnic and Racial Studies, vol. 36, no. 4, pp. 691-710.

Pedersen, O K 2011a, Folkeskolen og Politisk Kultur, Politik, vol. 14, no. 2, pp. 11-18.

Pedersen, O K 2011b, Konkurrencestaten, Hans Reitzels Forlag, København.

Regeringen 2009, En falles og tryg fremtid. Handlingsplan om forebyggelse af ekstremistiske holdninger og radikalisering blandt unge. Copenhagen: Danish Government. URL: http://www.nyidanmark.dk/ NR/rdonlyres/4443E64E-3DEA-49B2-8E19- B4380D52F1D3/0/ handlingsplan_radikalisering_2009.pdf

Ross, A 1966, Dansk statsforfatningsret II, Nyt Nordisk Forlag, København. 
Torfing, J 2004, Det stille sporskifte i velfardsstaten: en diskursteoretisk beslutningsprocesanalyse, Aarhus Universitetsforlag, Aarhus.

Uddannelsesudvalget 2005, Betænkning afgivet af uddannelsesudvalget den 21. april 2005, Folketinget.

Undervisningsministerieret 2009, Indikatorbaseret model for tilsynet med frihed og folkestyre. København: Undervisningsministeriet. URL: http://www.ktst.dk/frie\%20skoler//media/Styrelsen/Friskoleomraadet/Indikatorbaseret $\% 20$ model $\% 20$ for $\% 20$ tilsynet $\% 20$ med $\% 20$ frihed $\% 20$ og $\% 20$ folkestyre.ashx

\section{Noter}

1. Dansk Friskoleforening og dens medlemmer er arvtagerne til Grundtvig og Kold. Ikke alle frie grundskoler baserer sig historisk på friskolebevægelsen/traditionen. Det gælder fx medlemmerne af Danmarks Privatskoleforening, som i mange tilfælde er forhenværende private realskoler (Larsen 2010), og de katolske skoler. Foreningen af Kristne Friskolers medlemmer baserer sig heller ikke på grundtvigianismen. Lilleskolerne har historisk udspring i reform- pædagogikken. I dag reguleres alle skoler, samlet kaldet 'de frie grundskoler', af den samme lov. Af læsbarhedshensyn skelnes der i det følgende ikke mellem friskoler, privatskoler og frie grundskoler. Friskoletraditionen står helt centralt i den politiske debat om de frie grundskolers frihed og legitimeringen af dens regulering.

2. De resterende går på efterskoler og forskellige former for specialskoler.

3. Skolerne skal have slutmål for de tre hovedområder, humanistiske fag, naturvidenskabelige fag og de praktisk-musiske fag og delmål for dansk, engelsk, matematik/regning, geografi, biologi og fysik/ kemi. Undervisningsplanerne skal vise, hvordan skolernes undervisning på de tre hovedområder står mål med folkeskolens.

4. Lovforslaget henviser direkte til 'reglerne for hjemmeundervisning'. Muligvis skal hjemmeundervisning dog 'stå mål med' folkeskolens formålsparagrafs bestemmelser om forberedelse til frihed og folkestyre, hvilket helt ville udelukke denne form for undervisning. Der foreligger ingen retsafgørelser vedrørende dette.

5. For nogle skoler er det selvfølgelig vanskeliggjort af, at deres pædagogiske grundlag tilsiger, at man ikke bør eksaminere - eller ikke eksaminere på bestemte måder. 